AL-IQTISHOD: Jurnal Pemikiran dan Penelitian Ekonomi Islam

E-ISSN: 2745-85I2 P-ISSN: 2407-6600

Volume 9 Issue I Januari 202I | Page: 036-054

DOI: $\operatorname{xxxxxxxxxxxxxxx}$

\title{
EKSISTENSI NILAI AL 'ADALAH \\ PADA KEBIJAKAN ZAKAT DI INDONESIA
}

\section{Muslih Aris}

STAI Daruttaqwa Gresik

arismuslih@gmail.com

\begin{abstract}
Islamic economic theories and concepts contain deeply rooted values and give rise to unique characteristics that are not shared by conventional economic theories or concepts. Islamic economic philosophy refers to the nature of humans as humans (human dimension) and humans as servants of Allah (illahiyyah dimension). Tawhid is the highest value in the philosophy of the Islamic economic system because besides Allah (being) is a manifestation of one illahiyah then the emergence of gradations from the main reality (Allah) which makes the difference appear (exist). Tawhid then branched off from other values which were crystallized into the concept of mashlahah, the concept of ownership and the concept of the caliphate. Mashlahah consists of the value of justice, the value of brotherhood, the value of freedom and responsibility. The concept of justice demands a fair and equitable distribution and redistribution of wealth to the people. The interest of zakat really needs to be considered in government policies, not only because zakat is a source of large and very potential state income but more on the value of justice contained in zakat for realizing people's welfare.
\end{abstract}

Keywords: Philosophy, Sharia Economics, al Adalah, Zakat

Abstrak: Teori dan konsep ekonomi Islam mengandung nilai-nilai yang mengakar kuat dan menimbulkan karakter unik yang tidak dimiliki oleh teori maupun konsep ekonomi konvensional. Filsafat ekonomi Islam merujuk pada hakikat manusia sebagai manusia (dimensi insaniyyah) dan manusia sebagai hamba Allah (dimensi illahiyyah). Tauhid adalah nilai tertinggi dalam falsafah sistem ekonomi islam karena selain Allah (makhluk) merupakan manifestasi illahiyah yang satu kemudian munculnya gradasi-gradasi dari realitas utama (Allah) yang membuat perbedaan itu maujud (ada). Tauhid kemudian bercabang pada nilai-nilai lain yang terkristal ke dalam konsep mashlahah, konsep kepemilikan dan konsep kekhalifahan. Mashlahah terdiri dari nilai keadilan, nilai persaudaraan, nilai kebebasan dan tanggung jawab. Konsep keadilan menuntut adanya distribusi dan redistribusi kekayaan yang adil dan merata kepada rakyat. Kepentingan zakat sangat perlu dipertimbangkan dalam kebijakan-kebijakan pemerintah, tidak hanya karena zakat merupakan salah satu sumber pemasukan negara yang besar dan sangat potensial akan tetapi lebih pada nilai keadilan yang terkandung dalam zakat untuk mewujudkan kesejahteraantakyat.

Kata Kunci: Filsafat, Ekonomi Syariah, al 'Adalah, Zakat 
Eksistensi nilai al-Adalah ....

\section{A. Pendahuluan}

Keadilan merupakan pilar terpenting dalam ekonomi Islam. Penegakkan keadilan telah terbingkai indah dalam Al-Qur'an sebagai misi utama para Nabi dan Rasultermasuk penegakkan keadilan ekonomi dan penghapusan kesenjangan pendapatan. Dalam surat al Hadid ayat 25 Allah berfirman:

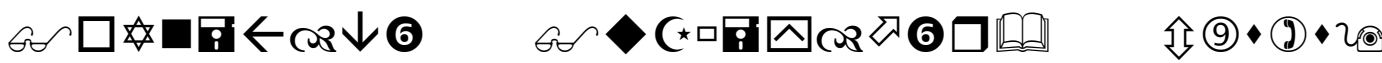

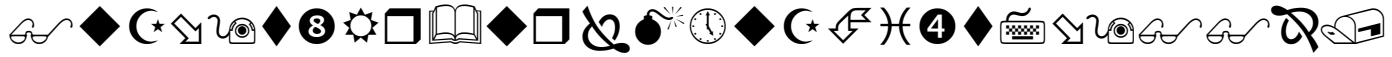

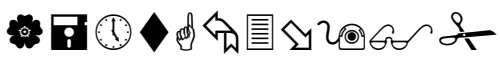
$\boldsymbol{U}$ 的 $\leftarrow \eta_{0} \triangle \rightarrow \rightarrow$ है।

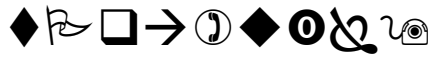

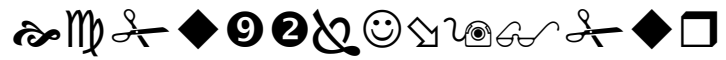

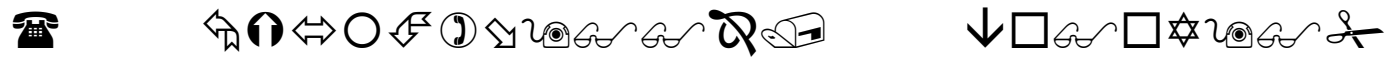

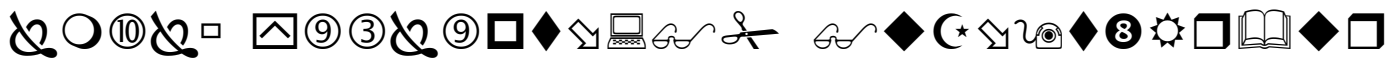

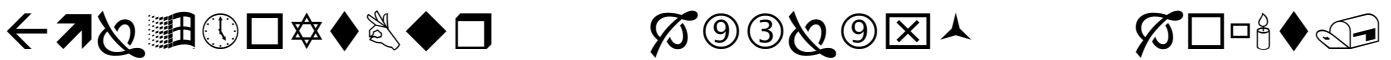

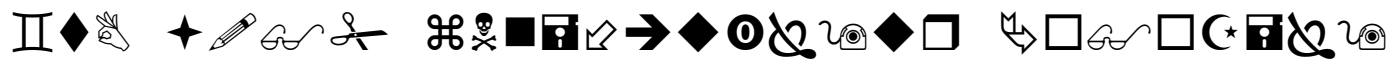

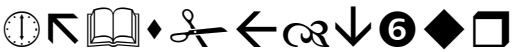
(1)

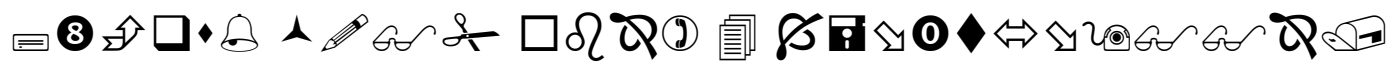

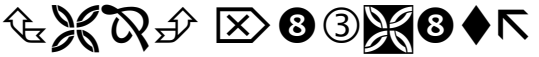

"Sesungguhnya Kami telah mengutus Rasul-rasul Kami dengan membawa buktibukti yang nyata dan telah Kami turunkan bersama mereka Al kitab dan neraca (keadilan) supaya manusia dapat melaksanakan keadilan. dan Kami ciptakan besi yang padanya terdapat kekuatan yang hebat dan berbagai manfaat bagi manusia, (supaya mereka mempergunakan besi itu) dan supaya Allah mengetahui siapa yang menolong (agama)Nya dan rasul-rasul-Nya Padahal Allah tidak dilihatnya. Sesungguhnya Allah Maha kuat lagi Maha Perkasa".(Q.S. Al Hadid:25)I

Resesi ekonomi Indonesia saat pandemi covid-19 yang semakin mengkhawatirkan menjadi pekerjaan rumah yang mendesak bagi bangsa. Walaupun pengembangan ekonomi syariah di Indonesiua terus digalakkan, namun masih tetap dianggap sebelah mata

'Bahreisy, Salim, I995, Terjemah al Qur'an al Hakim, Surabaya, CV al Qolam, hal, 542

36| A1-Iqtishod Volume.9/No. I/Januari 202I 
dalam menyembuhkan problem ekonomi Indonesia karena dianggap tidak representative membangun kekuatan perekonomian. Padahal, Islam adalah agama mayoritas di Indonesia yang secara tidak langsung akan merasakan dampak- dampak yang ditimbulkan oleh keterpurukan ekonomi.

Indonesia sebagai salah satu negara berkembang tidak luput dari persoalanpersoalan ekonomi. Salah satu persoalan nyata yang harus dihadapi bangsa ini adalah disparitas (ketimpangan) distribusi pendapatan yang menyebabkan kemiskinan. Realita kemiskinan dilatar belakangi oleh ketidakadilan, ketimpangan dan penyimpangan distribusi sumber daya untuki rakyat telah mengakibatkan tidak terwujud nya pemerataan ekonomi, karena manajemen distribusi yang buruk. Padahal distribusi merupakan aktivitas perekonomian yang penting dalam Islam. Jika distribusi kekayaan berjalan dengan baik, maka harta atau kekayaan akan tersebar luas dan tidak terjadi penumpukan harta atau kekayaan pada golongan tertentu.

Sebagai salah satu aktivitas perekonomian, distribusi menjadi bidang kajian terpenting dalam perekonomian. Distribusi juga memiliki posisi terpenting dari teori mikro Islam karena pembahasan dalam bidang distribusi tidak berkaitan dengan aspek ekonomi saja akan tetapi aspek sosial politik sehingga menjadi perhatian bagi aliran pemikir ekonomi Islam dan konvensional sampai saat ini.

Sistem ekonomi Islam menghendaki bahwa dalam hal pendistribusian harus didasarkan pada dua sendi, yaitu kebebasan dan keadilan ${ }^{2}$. Kebebasan bermakna ekonomi merupakan tindakan yang bebas dilakukan oleh manusia dengan pihak manapun akan tetapi ada suatu nilai- nilai tauhid yang menjadi batasan-batasan terhadap kebebasan bertindak. Sedangkan makna keadilan dalam pendistribusian sumber daya tercermin dalam Q.S Al-Hasyr ayat tujuh, bahwa harta atau kekayaan harus beredar dan jangan sampai berputas di golongan tertentu saja agar terwujud suatu pemerataan ekonomi dan mewujudkan kesejahteraan.

\footnotetext{
${ }^{2}$ Qardhawi, Yusuf. 2007. Norma dan Etika Ekonomi Islam. Jakarta: Gema Insani Press, hal,54
}

Volume. 9/No. I/Januari 202I A1-Iqtishod|37 
Eksistensi nilai al-Adalah ....

Distribusi berhubungan erat dengan pemerataan demi terwujudnya suatu keadilan. Keadilan sosial juga berarti mempersempit jurang pemisah antara individu maupun golongan satu sama lain dengan membatasi keserakahan orang-orang kaya di satu sisi dan meningkatkan taraf hidup orang-orang fakir miskin di sisi lain. Dalam filsafat ekonomi islam, keadilan merupakan nilai yang menjadi jalan menuju tujuan utama yakni, kesejahteraan. $^{3}$

Dalam bidang ekonomi, orang dapat menyatakan bahwa keadilan menuntut penggunaan sumberdaya dengan cara yang merata sehingga tujuan kemanusiaan yang dihargai secara universal yaitu pemenuhan kebutuhan umum, pertumbuhan yang optimal, lapangan pekerjaan yang lengkap, pemerataan pendapatan dan kekayaan dan kestabilan ekonomi terwujud. ${ }^{4}$

Keadilan hanya bisa dipahami jika ia diposisikan sebagai keadaan yang hendak diwujudkan oleh hukum. Upaya untuk mewujudkan keadilan dalam hukum tersebut merupakan proses yang dinamis yang memakan banyak waktu. Upaya ini seringkali didominasi oleh kekuatan-kekuatan yang bertarung dalam kerangka umum tatanan politik untuk mengaktualisasikannya. ${ }^{5}$

Allah SWT di dalam Al-Quran telah mengatur segala kebijakan-kebijakan yang wajib manusia taati, sabda-sabda Rasulullah SAW juga merupakan gambaran sederhana dari nilai-nilai Al-Quran yang mengatur tatanan hidup manusia. Penegakan keadilan ditekankan dalam Al-Quran sebagai misi utama para nabi yang diutus Allah. Penegakan keadilan ini termasuk keadilan ekonomi dan penghapusan kesenjangan pendapatan. Islam adalah agama rahmatan lil „alamin sangat mengutamakan adanya keadilan dalam setiap sektor, baik ekonomi, politik maupun sosial. Berbeda dengan keadilan dalam sistem ekonomi sosialis dan kapitalis seperti tidak punya ruh kemanusiaan, kedua sistem tersebut

\footnotetext{
${ }^{3}$ Jusmaliani, dkk. 2005. Kebijakan Ekonomi dalam Islam. Yogyakarta: Kreasi Wacana, hal, I22

${ }^{4}$ Chapra, M. Umar. 1985. Toward a Just Monetary System. Leiceste: UK Foundation, hal, 76

${ }^{5}$ Friedrich, Carl Joachim. 2004. Filsafat Hukum Perspektif Historis. Bandung: Nuansa dan Nusa Media, hal I9I
}

38| A1-Iqtishod Volume. 9/No. I/Januari 202I 
acuh terhadap ukhuwah (persaudaraan). Tekanan terhadap individu atau kelompok semakin menyudutkan kedua sistem ekonomi tersebut sehingga tujuan-tujuan keadilan sosial mustahil untuk diwujudkan.

Zakat adalah merupakan salah satu nilai instrumental yang strategis dalam sistem ekonomi islam yang dapat mempengaruhi tingkah laku ekonomi seorang muslim, masyarakat dan pembangunan ekonomi pada umumnya. Sistem ekonomi Islam itu sendiri adalah sistem yang terjadi setelah prinsip ekonomi yang menjadi pedoman kerjanya, dipengaruhi atau dibatasi oleh ajaran-ajaran $\mathrm{Islam}^{6}$. Keadilan merupakan suatu prinsip, dasar dan landasan sistem ekonomi Islam berdasarkan syariat yang berkeadilan. Oleh karena itu, praktek ekonomi apapun yang bertolak belakang dengan nilai keadilan akan dikecam keras.

Aspek pendistribusian harta atau kekayaan menurut instrument islam salah satunya adalah zakat. Zakat merupakan sumber penerimaan negara terbesar pada awal sejarah islam. Dibandingkan dengan sumber penerimaan negara yang lain misalnya, ghanimah, jizyah, fai", kharaj, zakat menempati urutan pertama. Zakat dianggap sebagai "a school of thought" sekaligus sebagai "a microcosm of the entire Islamic Fiscal System".

Zakat sebagai salah satu doktrin ekonomi Islam dapat diarahkan pada usaha pemerataan ekonomi masyarakat. Jika zakat dapat dikelola efektif dan efisien akan terjadi keseimbangan sirkulasi ekonomi masyarakat. Masyarakat miskin akan mendapatkan hak yang lebih baik untuk mencukupi kebutuhan primer. Dengan demikian, zakat telah berhasil menjadi suatu instrument pengentasan kemiskinan, sebagai solusi pemerataan ekonomi dan menanggalkan kesenjangan ekonomi antara kelompok kaya dan kelompok miskin yang kemudian akan memperkuat ketahanan ekonomi serta mendorong pembangunan perekonomian bangsa.

\footnotetext{
${ }^{6}$ Ali, Mohammad Daud. 1998. Sistem Ekonomi Islam Zakat dan Wakaf. Jakarta: UI Press, hal I07

7 Suwarsono. 1992. Pendapatan dan Belanja Negara dan Regulasi Ekonomi dalam Ekonomi Islam dalam Sistem Ekonomi Islam. Yogyakarta: Tiara Wacana dan LP3EI UII,hal 39
}

Volume. 9/No. I/Januari 202I A1-Iqtishod|39 
Eksistensi nilai al-Adalah ....

Pendistribusian pendapatan secara adil dan merata adalah cara paling efektif untuk mencapai peningkatan pendapatan secara simultan di lapisan masyarakat. Produksi kekayaan yang meningkat tidak akan bisa mendongkrak pertumbuhan ekonomi umat jika tidak diimbangi dengan pendistribusiannya. Islam muncul sebagai sistem nilai yang mewarnai perilaku ekonomi masyarakat muslim Indonesia. Dalam hal ini, zakat memiliki potensi strategis yang layak dikembangkan menjadi istrumen pemerataan pendapatan di Indonesia. Sehingga diharapkan bisa mempengaruhi aktivas ekonomi nasional, khususnya penguatan pemberdayaan ekonomi umat.

Kebijakan-kebijakan tentang zakat di Indonesia mengalami kekalutan. Belum terlihatnya efektifitas lembaga zakat terkait pengumpulan, administrasi pendistribusian, monitoring serta evaluasi. Dalam membuat kebijakan zakat, pemerintah diharapkan mampu memunculkan suatu nilai keadilan. Karena bagaimanapun juga suatu sistem ekonomi tanpa suntikan nilai keadilan maka akan hilang ruhnya. Apalagi zakat yang jelasjelas perintah dari Allah SWT dan termaktub dalam Al-Quran Al Karim. Dengan demikian pemerintah harus berusaha menentukan kebijakan bagi pengelolaan zakat di Indonesia dengan tidak mengesampingkan nilai keadilan. Keadilan merupakan pilar terpenting dalam ekonomi Islam. Penegakkan keadilan telah terbingkai indah dalam AlQur'an sebagai misi utama para Nabi dan Rasultermasuk penegakkan keadilan ekonomi dan penghapusan kesenjangan pendapatan.

Resesi ekonomi Indonesia saat pandemi covid-I9 yang semakin mengkhawatirkan menjadi pekerjaan rumah yang mendesak bagi bangsa. Walaupun pengembangan ekonomi syariah di Indonesiua terus digalakkan, namun masih tetap dianggap sebelah mata dalam menyembuhkan problem ekonomi Indonesia karena dianggap tidak representative membangun kekuatan perekonomian. Padahal, Islam adalah agama mayoritas di Indonesia yang secara tidak langsung akan merasakan dampak- dampak yang ditimbulkan oleh keterpurukan ekonomi.

Indonesia sebagai salah satu negara berkembang tidak luput dari persoalanpersoalan ekonomi. Salah satu persoalan nyata yang harus dihadapi bangsa ini adalah 
disparitas (ketimpangan) distribusi pendapatan yang menyebabkan kemiskinan. Realita kemiskinan dilatar belakangi oleh ketidakadilan, ketimpangan dan penyimpangan distribusi sumber daya untuki rakyat telah mengakibatkan tidak terwujudnya pemerataan ekonomi, karena manajemen distribusi yang buruk. Padahal distribusi merupakan aktivitas perekonomian yang penting dalam Islam. Jika distribusi kekayaan berjalan dengan baik, maka harta atau kekayaan akan tersebar luas dan tidak terjadi penumpukan harta atau kekayaan pada golongan tertentu.

Sebagai salah satu aktivitas perekonomian, distribusi menjadi bidang kajian terpenting dalam perekonomian. Distribusi juga memiliki posisi terpenting dari teori mikro Islam karena pembahasan dalam bidang distribusi tidak berkaitan dengan aspek ekonomi saja akan tetapi aspek sosial politik sehingga menjadi perhatian bagi aliran pemikir ekonomi Islam dan konvensional sampai saat ini. ${ }^{8}$

Sistem ekonomi Islam menghendaki bahwa dalam hal pendistribusian harus didasarkan pada dua sendi, yaitu kebebasan dan keadilan 9. Kebebasan bermakna ekonomi merupakan tindakan yang bebas dilakukan oleh manusia dengan pihak manapun akan tetapi ada suatu nilai- nilai tauhid yang menjadi batasan-batasan terhadap kebebasan bertindak. Sedangkan makna keadilan dalam pendistribusian sumber daya tercermin dalam Q.S Al-Hasyr ayat tujuh, bahwa harta atau kekayaan harus beredar dan jangan sampai berputas di golongan tertentu saja agar terwujud suatu pemerataan ekonomi dan mewujudkan kesejahteraan.

Distribusi berhubungan erat dengan pemerataan demi terwujudnya suatu keadilan. Keadilan sosial juga berarti mempersempit jurang pemisah antara individu maupun golongan satu sama lain dengan membatasi keserakahan orang-orang kaya di satu sisi dan meningkatkan taraf hidup orang-orang fakir miskin di sisi lain. Dalam filsafat ekonomi islam, keadilan merupakan nilai yang menjadi jalan menuju tujuan utama yakni,

\footnotetext{
${ }^{8}$ Muhammad Kambali, "Analisis Peran Negara Di Bidang Ekonomi Dalam Prespektif Sistem Kapitalisme, Sosialisme, Dan Ekonomi Islam,” JES (Jurnal Ekonomi Syariah), 2016, https://doi.org/I0.30736/jes.vIiI.2.

${ }^{9}$ Qardhawi, Yusuf. 2007. Norma dan Etika Ekonomi Islam. Jakarta: Gema Insani Press, hal,54
}

Volume. 9/No. I/Januari 202I Al-Iqtishod|4I 
Eksistensi nilai al-Adalah ....

kesejahteraan. ${ }^{10}$

Dalam bidang ekonomi, orang dapat menyatakan bahwa keadilan menuntut penggunaan sumberdaya dengan cara yang merata sehingga tujuan kemanusiaan yang dihargai secara universal yaitu pemenuhan kebutuhan umum, pertumbuhan yang optimal, lapangan pekerjaan yang lengkap, pemerataan pendapatan dan kekayaan dan kestabilan ekonomi terwujud. ${ }^{\text {II }}$

Keadilan hanya bisa dipahami jika ia diposisikan sebagai keadaan yang hendak diwujudkan oleh hukum. Upaya untuk mewujudkan keadilan dalam hukum tersebut merupakan proses yang dinamis yang memakan banyak waktu. Upaya ini seringkali didominasi oleh kekuatan-kekuatan yang bertarung dalam kerangka umum tatanan politik untuk mengaktualisasikannya. ${ }^{12}$

Allah SWT di dalam Al-Quran telah mengatur segala kebijakan-kebijakan yang wajib manusia taati, sabda-sabda Rasulullah SAW juga merupakan gambaran sederhana dari nilai-nilai Al-Quran yang mengatur tatanan hidup manusia. Penegakan keadilan ditekankan dalam Al-Quran sebagai misi utama para nabi yang diutus Allah. Penegakan keadilan ini termasuk keadilan ekonomi dan penghapusan kesenjangan pendapatan. Islam adalah agama rahmatan lil ,alamin sangat mengutamakan adanya keadilan dalam setiap sektor, baik ekonomi, politik maupun sosial. Berbeda dengan keadilan dalam sistem ekonomi sosialis dan kapitalis seperti tidak punya ruh kemanusiaan, kedua sistem tersebut acuh terhadap ukhuwah (persaudaraan). Tekanan terhadap individu atau kelompok semakin menyudutkan kedua sistem ekonomi tersebut sehingga tujuan-tujuan keadilan sosial mustahil untuk diwujudkan.

Zakat adalah merupakan salah satu nilai instrumental yang strategis dalam sistem ekonomi islam yang dapat mempengaruhi tingkah laku ekonomi seorang muslim, masyarakat dan pembangunan ekonomi pada umumnya. Sistem ekonomi Islam itu sendiri adalah sistem yang terjadi setelah prinsip ekonomi yang menjadi pedoman kerjanya,

${ }^{10}$ Jusmaliani, dkk. 2005. Kebijakan Ekonomi dalam Islam. Yogyakarta: Kreasi Wacana, hal, I22

${ }^{11}$ Chapra, M. Umar. 1985. Toward a Just Monetary System. Leiceste: UK Foundation, hal, 76

${ }_{12}$ Friedrich, Carl Joachim. 2004. Filsafat Hukum Perspektif Historis. Bandung: Nuansa dan Nusa Media, hal I9I

42| A1-Iqtishod Volume.9/No. I/Januari 202I 
dipengaruhi atau dibatasi oleh ajaran-ajaran $\mathrm{Islam}^{13}$. Keadilan merupakan suatu prinsip, dasar dan landasan sistem ekonomi Islam berdasarkan syariat yang berkeadilan. Oleh karena itu, praktek ekonomi apapun yang bertolak belakang dengan nilai keadilan akan dikecam keras.

Aspek pendistribusian harta atau kekayaan menurut instrument islam salah satunya adalah zakat. Zakat merupakan sumber penerimaan negara terbesar pada awal sejarah islam. Dibandingkan dengan sumber penerimaan negara yang lain misalnya, ghanimah, jizyah, fai", kharaj, zakat menempati urutan pertama. Zakat dianggap sebagai "a school of thought" sekaligus sebagai "a microcosm of the entire Islamic Fiscal System" "It.

Zakat sebagai salah satu doktrin ekonomi Islam dapat diarahkan pada usaha pemerataan ekonomi masyarakat. Jika zakat dapat dikelola efektif dan efisien akan terjadi keseimbangan sirkulasi ekonomi masyarakat. Masyarakat miskin akan mendapatkan hak yang lebih baik untuk mencukupi kebutuhan primer. Dengan demikian, zakat telah berhasil menjadi suatu instrument pengentasan kemiskinan, sebagai solusi pemerataan ekonomi dan menanggalkan kesenjangan ekonomi antara kelompok kaya dan kelompok miskin yang kemudian akan memperkuat ketahanan ekonomi serta mendorong pembangunan perekonomian bangsa.

Pendistribusian pendapatan secara adil dan merata adalah cara paling efektif untuk mencapai peningkatan pendapatan secara simultan di lapisan masyarakat. Produksi kekayaan yang meningkat tidak akan bisa mendongkrak pertumbuhan ekonomi umat jika tidak diimbangi dengan pendistribusiannya. Islam muncul sebagai sistem nilai yang mewarnai perilaku ekonomi masyarakat muslim Indonesia. Dalam hal ini, zakat memiliki potensi strategis yang layak dikembangkan menjadi istrumen pemerataan pendapatan di Indonesia. Sehingga diharapkan bisa mempengaruhi aktivas ekonomi nasional, khususnya penguatan pemberdayaan ekonomi umat.

Kebijakan-kebijakan tentang zakat di Indonesia mengalami kekalutan. Belum

\footnotetext{
${ }^{13}$ Ali, Mohammad Daud. 1998. Sistem Ekonomi Islam Zakat dan Wakaf. Jakarta: UI Press, hal I07

I4 Suwarsono. 1992. Pendapatan dan Belanja Negara dan Regulasi Ekonomi dalam Ekonomi Islam dalam Sistem Ekonomi Islam. Yogyakarta: Tiara Wacana dan LP3EI UII,hal 39
}

Volume. 9/No. I/Januari 202I A1-Iqtishod|43 
Eksistensi nilai al-Adalah ....

terlihatnya efektifitas lembaga zakat terkait pengumpulan, administrasi pendistribusian, monitoring serta evaluasi. Dalam membuat kebijakan zakat, pemerintah diharapkan mampu memunculkan suatu nilai keadilan. Karena bagaimanapun juga suatu sistem ekonomi tanpa suntikan nilai keadilan maka akan hilang ruhnya. Apalagi zakat yang jelasjelas perintah dari Allah SWT dan termaktub dalam Al-Quran Al Karim. Dengan demikian pemerintah harus berusaha menentukan kebijakan bagi pengelolaan zakat di Indonesia dengan tidak mengesampingkan nilai keadilan.

\section{B. Kajian Pustaka}

\section{Konsep Nilai Keadilan}

Ibnu Sina menegaskan bahwa manusia dalam berekonomi membutuhkan aturan agar tercipta keadilan. Pendapat tegas Ibnu Sina adalah ekonomi tidak hanya lahir dari suatu kerjasama melainkan dari kepastian hukum yang adil. Oleh karenanya, bermacam-macam kegiatan ekonomi harus ada hukum (sunnah) dan keadilan. Tauhid diperlukan agar setian individu memahamibahwa Allah Yang Esa mengetahui segala hal yang tidak tersembunyi maupun tersembunyi ${ }^{15}$.

Keberadaan nabi adalah mengatur dan menegakkan keadilan. Hal ini berarti dalam melakukan aktivitas ekonomi manusia, penegakan sangat dibutuhkan setelah hukum. Keadilan bertujuan menjamin harmonisasi sosial yang mencegah perselisihan dan kesenjangan ekonomi masyarakat. Keadilan merupakan muara dari keefektifan distribusi barang akan tetapi keadilan bisa saja musnah jika keefektifan tidak terwujud karena tidak adanya usaha manusia dalam memahami kemudian menggabungkan keadilan dan kearifan teoritis.

Kitab Al Amwal berfokus pada standar etika politik suatu pemerintahan, ia juga membahas keadilan redistribusi dari sisi "apa" dan bukan "bagaimana”. Kitab Al Amwal berisi masalah keuangan publik juga administrasi pemerintahan secara umum. Kitab Al Amwal menekankan beberapa isu mengenai perpajakan dan hukum

\footnotetext{
${ }^{15}$ Athoillah, M. Anthon dan Bambang Q-Anees. 2013. Filsafat Ekonomi Islam. Yogyakarta: Sahifa, hal, 91
} 
pertanahan serta hukum administrasi dan hukum internasional ${ }^{16}$.

Zakat adalah ibadah maliyah ijtima ${ }^{e c}$ iyyah yang memiliki posisi yang sangat penting, strategis dan menentukan baik dari sisi ajaran maupun dari sisi pembangunan kesejahteraan ummat $^{17}$. Pernyataan itu mencerminkan zakat tidak hanya sebagai ibadah mahdhah saja akan tetapi juga mengandung fungsi-fungsi sosial.

Zakat merupakan rukun islam ketiga dan sebagai satu-satunya rukun yang memiliki dua dimensi, yaitu dimensi illahiyah dan dimensi insaniyah. Zakat berdimensi illahiyah adalah Allah memerintahkan kaum muslim untuk berzakat dan jika seorang muslim mengamalkannya, melakukannya, melaksanakannya maka kaum muslim akan mendapat pahala sekaligus terhindar dari dosa. Akan tetapi dimensi insaniyah mengantarkan zakat pada suatu lingkup kehidupan sosial masyarakat sebagai instrumen pelebur ketidakadilan, disparitas (ketimpangan), kesenjangan.

Keadilan menjadi sorotan utama dalam mekanisme distribusi kekayaan dan zakat menjadi suatu kewajiban yang harus ditunaikan (perintah Allah) dan lebih baik jika kau muslim menyadari manfaat zakat. Zakat tidak hanya sebagai perintah yang harus ditunaikan kemudian berhenti sampai titik kewajiban saja tetapi sebagai penyokong kesejahteraan manusia di bumi. Melalui distribusi pendapatan yang merata maka keadilan akan terwujud, jika keadilan terwujud maka kesejahteraan manusia tercapai.

Motor penggerak suatu sistem ekonomi bukanlah pemenuhan opitimalisasi kepentingan-kepentingan segelintir orang saja, lebih dari itu pemenuhan kesejahteraan bersama dengan rasa keadilan lah yang harus diperjuangkan. Rasa keadilan yang dimaksud adalah memberikan kepuasanbatin untuk banyak orang tanpa pengorbanan diri sendiri. Inilah falsafah ekonomi islam yang seharusnya dipahami dan diwujudkan dalam kehidupan.

\section{Landasan Al-Quran dan As-Sunnah}

\footnotetext{
${ }^{16}$ Karim, Adiwarman. 2003. Ekonomi Makro Islami. Jakarta: IIIT Indonesia, hal, 56

${ }^{17}$ Qardhawi, Yusuf, ibid, hal, I95
}

Volume. 9/No. I/Januari 202I A1-Iqtishod|45 
Eksistensi nilai al-Adalah ....

a. Q.S Al-Bayyinah [98]: 5

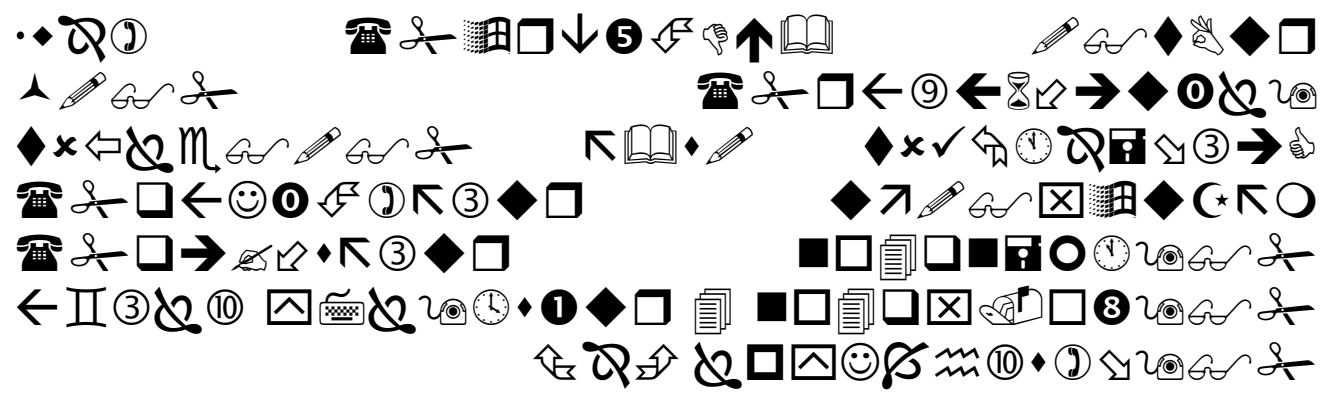

"Padahal mereka tidak disuruh kecuali supaya menyembah Allah dengan memurnikan ketaatan kepada-Nya dalam (menjalankan) agama yang lurus dan supaya mereka mendirikan shalat dan menunaikan zakat; dan yang demikian Itulah agama yang lurus." ${ }^{\prime s}$

b. Q.S At-Taubah [9] : 103

Cロ・A口(9)

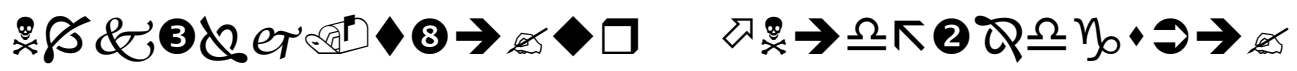

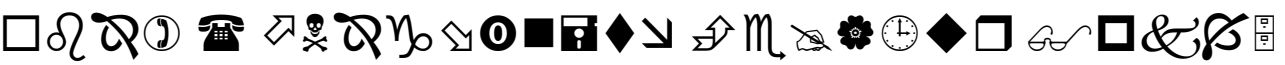

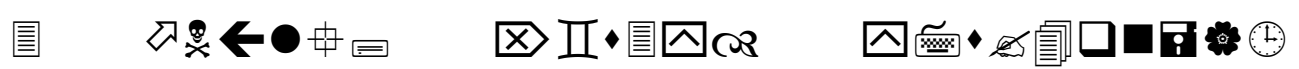

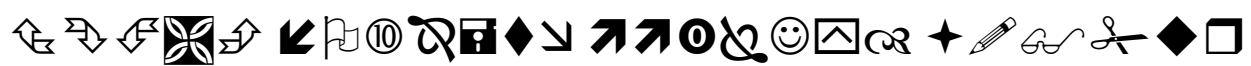

"Ambillah zakat dari sebagian harta mereka, dengan zakat itu kamu membersihkan dan mensucikan mereka dan mendoalah untuk mereka. Sesungguhnya doa kamu itu (menjadi) ketenteraman jiwa bagi mereka. dan Allah Maha mendengar lagi Maha mengetahui." ${ }^{19}$

c. Q.S Al-Hajj [22] : $4 \mathrm{I}$

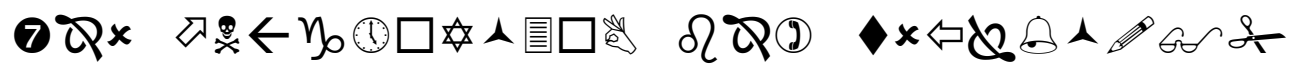

苗 \& $\square$ तथ

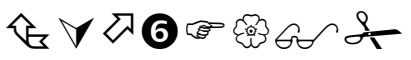

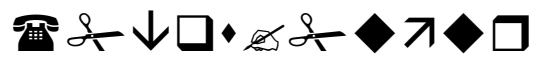

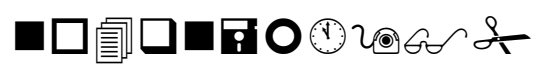

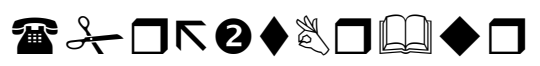

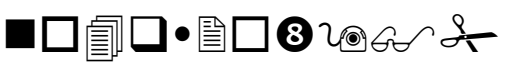

${ }^{18}$ Baheirsy, Salim, Ibid, hal, 599

${ }^{19}$ Ibid, hal, 204

46| Al-Iqtishod Volume. 9/No. I/Januari 202I 


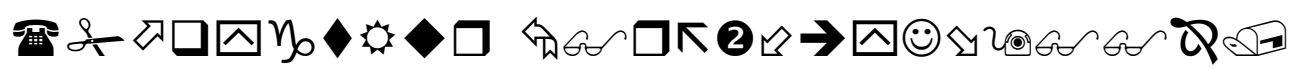
* $\quad$ 目

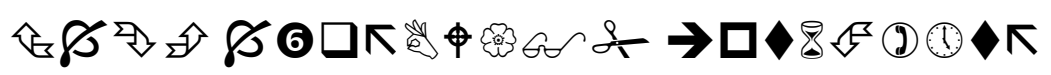

"(yaitu) orang-orang yang jika Kami teguhkan kedudukan mereka di muka bumi niscaya mereka mendirikan sembahyang, menunaikan zakat, menyuruh berbuat ma'ruf dan mencegah dari perbuatan yang mungkar; dan kepada Allah-lah kembali segala urusan. 20

d. Q.S Al-Mumtahanah [60]: 8

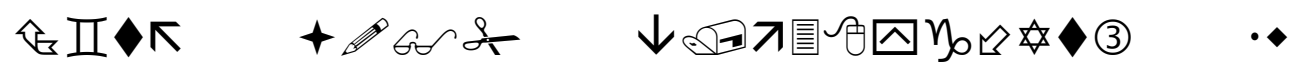

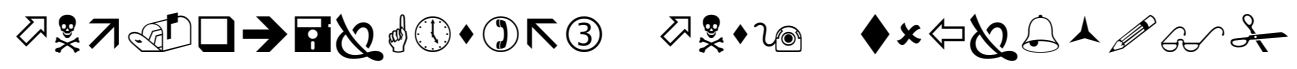

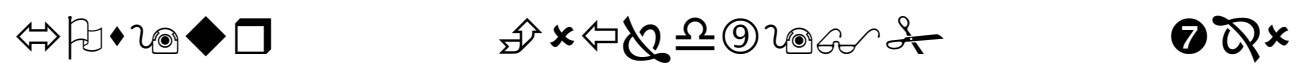
邓

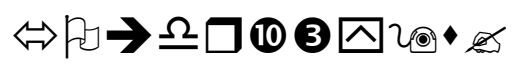
$\Omega \square[\square$ 亩 邓 4 穴 2 จ (6)

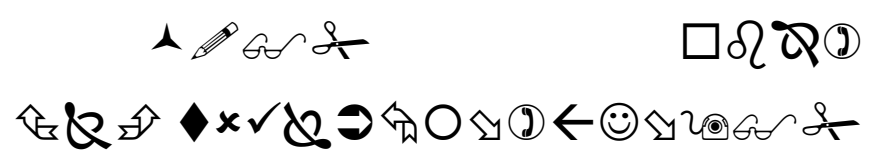

"Allah tidak melarang kamu untuk berbuat baik dan berlaku adil terhadap orangorang yang tiada memerangimu karena agama dan tidak (pula) mengusir kamu dari negerimu. Sesungguhnya Allah menyukai orang-orang yang berlaku adil."2I

e. HR. Ahmad, Nasai dan Abu Daud

"Barangsiapa menunaikan zakat karena mengharap pahala maka ia akan mendapatkannya. Tetapi barangsiappa menahannya, maka saya yang akan memungutnya beserta separuh hartanya, sebagai satu sitaan dari sitaan Tuhan kami dan tidak halal bagi keluarga Muhammad (Rasulullah SAW) sedikitpun daripadanya'?2

\section{Metode Penelitian}

\footnotetext{
${ }^{20}$ Ibid, hal, 338

${ }^{21}$ Ibid, hal, 55I

${ }^{22}$ Nasa ${ }^{\text {ee }}$, al. Sunan al Nasae i. 8 Juz. Bairut: Dar al Kitab
}

Volume. 9/No. I/Januari 202I A1-Iqtishod|47 
Eksistensi nilai al-Adalah ....

Untuk mengkaji penelitian ini maka digunakan metode kualitatif dengan melakukan pendekatan metode studil iteratur (library research).Penelitian ini dilakukan dengan membaca serta melakukan berbagai hal terutama mempelajari berbagai literature- literatur yang ada, yang didapatmelaluimetode documenter, yang bersumberdaribuku, jurnal, internet, danmakalah. ${ }^{23}$

Setelah semua data terkumpul kemudian data akan dianalisis dengan beberapa cara, diantaranya yaitu: Pertama, Interprestasi, adalah upaya tercapainya pemahaman yang benar terhadap fakta, data dan gejala. Kedua, koheresi intern, yaitu agar pemikiran tokoh dapat dipahami secara tepat, maka seluruh konsep pemikirannya dilihat menurut keselarasannya antara satu dengan yang lain. Ketiga, holistika adalah pandangan menyeluruh atau totalitasi; semua dipandang dalam kesinambungannya dengan satu totalitas. Keempat, heuristika yaitu berdasarkan bahan-bahan baru, metodologi baru, maka peneliti berusaha untuk menemukan pemahaman baru.

Setelah semua data terkumpul dan telah dilakukan analisa, maka dapat dijelaskan secara umum bagaimana hendaknya penelitian ini disusun secara disiplin agar isinya dapat dipahami secara runtut dan analistis.

\section{Hasil dan Pembahasan}

\section{Falsafah Zakat dalam Ekonomi Islam}

Zakat memiliki potensi psikologis untuk dijadikan sarana dalam meningkatkan kualitas kehidupan muslim secara internal maupun ekternal. Secara internal memiliki fungsi untuk membersihkan jiwa dari potensi “ serakah” terhadap apa yang dimiliki. Secara ekternal zakat berfungsi sebagai upaya yang mengatur terwujudnya keadilan sosial ekonomi dalam kehidupan masyarakat.

Semangat untuk "memberi" merupakan pesan utama yangingin disampaikan Allah kepada hamba-Nya. Wilayah ini lebih menjadi Wilayah "Filosofis". Sementara persoalan memberi apa, dari apa, berapa, dengan ketentuan seperti apa nampaknya

\footnotetext{
${ }^{23}$ Sugiyono, MetodePenelitianBisnis, (Alfabeta: Bandung, 20I4), hal. 399
}

48| A1-Iqtishod Volume. 9/No. I/Januari 202I 
merupakan persoalan teknis yang memang harus diperhatikan untuk memenuhi syarat dan rukun yang sesuai menurut ajaran Islam. Wilayah ini termasuk Wilayah Fiqh, dengan karakteristiknya dapat mengalami perubahan sesuai situasi dan kondisi ${ }^{24}$. Mengenai zakat profesi perlu ditempatkan dalam semangat filosofis, dalam segala bidang kajian ilmu falsafah menjadi bagian utama dan terpenting untuk terus digali sehingga menemukan akar yang kuat dalam penerapan keilmuan. Filsafat ekonomi merupakan dasar pondasi untukmembangun sebuah sistem ekonomi. Berdasar pada filsafat ekonomi yang ada maka akan muncul tujuan-tujuan yang hendak dicapai. Kegiatan ekonomi seperti produksi, distribusi, konsumsi, kebijakan moneter, kebijakan fiskal akan mudah diterapkan sesuai dengan falsafah yang sudah ada dan terlihat jelas.

Falsafah atau dasar menjadi pembeda yang kontras antara sistem ekonomi satu dan sistem ekonomi lainnya. Bukan berarti sistem ekonomi lain tidak berfalsafah, akan tetapi falsafah antar satu sistem ekonomi dan sistem lainnya akan berbeda dalam bertujuan dan mencapai tujuan. Sedangkan falsafah ekonomi islam memiliki dasar yang kuat, merujuk pada Al-Quran dan As Sunnah.

Dalam perekonomian Indonesia yang genting dan (mungkin) akan bertambah genting jika tidak kembali pada hakikat perekonomian itu sendiri. Jika falsafah yang menjadi akar sudah tidak dihiraukan, bagaimana bisa kita membuat bangunan yang kokoh? Karena hanya akar yang bisa menopang hidup, yang memberi arti dan pengertian, yang menentukan apakah bangunan akan kokoh atau roboh.

Filsafat ekonomi islam memiliki tiga konsep, yaitu filsafat Tuhan, filsafat manusia dan filsafat alam. Dimensi-dimensi itulah yang membuat praktek ekonomi Islam jauh berbeda dengan sistem kapitalis dan sistem sosialis atau liberalis. Filsafat ekonomi Islam selaras dengan nilai-nilai logis, etis dan estetis yang islami kemudian difungsionalkan ke dalam aktivitas ekonomi manusia. Karena Islam universal dan komprehensif, maka ekonomi menjadi salah satu instrumen terpenting dalam hubungan horizontal antar manusia-manusia dan manusia-alam. Nilai-nilai yang terkandung dalam falsafah lah yang

\footnotetext{
${ }^{24}$ Ibnu Qayyim al-Jauziyyah, Zaad al-Ma'ad, ( uwait: Daar el-Fikr, 1995), Juz 2, hal, 3
}

Volume. 9/No. I/Januari 202I A1-Iqtishod|49 
Eksistensi nilai al-Adalah ....

mendasari setiap kegiatan ekonomi Islam.

Asas falsafah zakat perlu dipahami untuk pelaksanaan dan fokus pada tujuantujuannya. Memahami zakat secara falsafah akan mempengaruhi bagaimana pelaksanaan sehingga zakat tidak didefinisikan sebagai ibadah wajib saja. Al-Quran yang merupakan sebuah falsafah hidup manusia dikaruniakan Allah untuk menata tata kehidupan manusia agar tegak di atas landasan taqwa. Isi kandungan Al-Quran yang komprehensif seharusnya menimbulkan rasa tanggung jawab manusia akan manusia dan alam sekitar.

\section{Urgensi Lembaga Amil dan Undang-undang Zakat}

Pengelolaan zakat oleh lembaga pengelola zakat, apalagi yang memiliki kekuatan hukum formal, akan memiliki beberapa keuntungan (Qadir, 1998), antara lain: Untuk menjamin kepastian dan disiplin pembayar zakat, Untuk menjaga perasaan rendah diri para mustahik zakat, Untuk mencapai efektifitas dan efisiensi penggunaan harta zakat menurut skala prioritas yang ada pada suatu tempat, serta untuk memperlihatkan syiar Islam ${ }^{25}$. Sebaliknya, jika zakat diserahkan langsung dari muzakki kepada mustahik, meskipun secara hukum syariah sah, namun selain akan terabaikannya hal-hal tersebut di atas, jugaberkurangnya cerminan hikmah dan fungsi zakat, terutama yang berkaitan dengan kesejahteraan umat.

Rasulullah saw pernah mempekerjakan seorang pemuda dari suku Asad, yang bernama Ibnu Lutaibah, untuk mengurus urusan zakat Bani Sulaim. Pernah pula mengutus Ali bin Abi Thalib ke Yaman untuk menjadi amil zakat ${ }^{26}$. Muaz bin Jabal pernah diutus Rasulullah saw pergi ke Yaman, di samping bertugas sebagai da ${ }^{\text {ee }} \mathrm{i}$ (menjelaskan ajaran Islam secara umum), juga mempunyai tugas khusus menjadi amil zakat (As-Sha'ani). Demikian pula yang dilakukan oleh para khulafaur-rasyidin sesudahnya, mereka selalu mempunyai petugas khusus yang mengatur masalah zakat, baik pengambilan maupun pendistribusiannya. Diambilnya zakat dari muzakki (orang yang memiliki kewajiban

\footnotetext{
${ }^{25}$ Ali, Mohammad Daud, ibid, hal, 72

${ }^{26}$ Schacht, Joseph, 1993, Encyclopedia of Islam, first ed., s.v. ,,zakat
}

50| A1-Iqtishod Volume. 9/No. I/Januari 202I 
berzakat) melalui amil zakat untuk kemudian disalurkan kepada mustahik, menunjukkan kewajiban zakat itu bukanlah semata-mata bersifat amal karitatif (kedermawanan), tetapi juga ia suatu kewajiban yang juga bersifat otoritatif (ijbari).

Potensi zakat yang begitu besar mengetuk hati pemerintah untuk menggali, memanfaatkan dan memberdayakan zakat secara professional. Untuk memenuhi targettarget pembangunan nasional melalui pemberdayaan zakat ini pemerintah bersama Dewan Perwakilan Rakyat RI menetapkan pengelolaan zakat secara berdayaguna dan berhasil guna melalui UU No. 38 Tahun 1999 tentang pengelolaan zakat dan telah ditindaklanjuti dengan Keputusan Menteri Agama No. 58I Tahun 1999 tentang pelaksanaan UndangUndang No. 38 Tahun 1999 tentang pengelolaan zakat. Keputusan Menteri Agama RI No. 373 Tahun 2003 tentang Pelaksanaan Undang-Undang No. 38 Tahun 1999 tentang Pengelolaan Zakat.

Latar belakang disusunnya Undang-Undang tentang Pengelolaan Zakat, yaitu: (i) Negara menjamin kemerdekaan tiap-tiap penduduk untuk beribadah menurut agamanya masing-masing (ii) Penunaian zakat merupakan kewajiban umat Islam dan sebagai sumber dana untuk kesejahteraan sosial masyarakat (iii) Zakat adalah suatu pranata agama untuk mewujudkan keadilan sosial (iv) Upaya sistem pengelolaan zakat perlu ditingkatkan agar benar-benar berdaya guna dan berdampak langsung pada masyarakat ${ }^{27}$. Dari latar belakang itulah mengapa kemudian disusun Undang-Undang Pengelolaan Zakat.

\section{Keberadaan Nilai al 'Adalah pada Kebijakan Zakat Indonesia}

Seperti yang telah dijelaskan sebelumnya, nilai keadilan merupakan falsafah zakat yang sekaligus menjadi tujuan pelaksanaan zakat itu sendiri. Keadilan menjadi jembatan awal terwujudnya suatu kesejahteraan. Pemerataan pendapatan di semua lapisan masyarakat akan membentuk suatu sistem yang berkeadilan, yang menjamah seluruh masyarakat tanpa

\footnotetext{
${ }^{27}$ Kementerian Keuangan Republik Indonesia. 2012. Laporan Kajian Islamic Publik Finance.
}

Volume. 9/No. I/Januari 202I A1-Iqtishod|5I 
Eksistensi nilai al-Adalah ....

adanya sekat-sekat yang memisahkan antara yang kaya dan miskin. ${ }^{28}$

Suatu bangunan dikatakan kokoh apabila pondasi yang menopangnya tertanam kuat. Begitupun bangunan zakat, sebagus apapun bentuk dan desainnya tanpa pondasi yang kokoh maka bangunan zakat itu tidak berarti apa-apa. Nilai keadilan merupakanruh dengan zakat sebagai jism (badan). Zakat berfungsi sebagai pengadaan ruh keadilan yang harus ditampilkan dalam kehidupan manusia. Sehingga nilai-nilai keadilan yang sebenarnya abstrak (tidak terlihat) menjadi nyata melalui implementasi pelaksanaan zakat.

Kebijakan-kebijakan yang telah disusun oleh pemerintah sejauh ini mengalami pro dan kontra antar individu maupun golongan. Ada yang berpendapat bahwa kebijakankebijakan yang telah disusun dan disahkan oleh pemerintah tidak berjalan dan seakan-akan hanya wacana saja tanpa adanya usaha yang jelas. Apalagi persoalan zakat dengan pajak yang menimbulkan kerancuan antara dua kewajiban warga negara dan umat beragama.

Jika dianalisis lebih lanjut, peran pemerintah dalam mengoptimalisasikan fungsi dan manfaat zakat yaitu: Pemerintah sebagai regulator, negara sebagai sebuah institusi yang berwenang mengeluarkan produk hukum melalui lembaga eksekutif dan legislasi dalam menetapkan hukum pelaksanaan, pengelolaan zakat yang efektif, profesional dan amanah. Negara sebagai Fasilitator, artinya negara turut serta dalam pengumpulan dana zakat dari muzakki. Negara sebagai motivator, artinya negara berperan dalam mendorong warga Indonesia yang beragama Islam untuk menjalankan kewajiban sebagai seorang muslim. Negara sebagai distributor, artinya negara berperan sebagai pengelola secara profesional dan transparan, mendistribusikan dana pengumpulan zakat lepada golongan yang masuk dalam kriteria mustahik.

Restrukturisasi kebijakan zakat di Indonesia yang berulang kali dikeluarkan pemerintah butuh persetujuan dari rakyat. Karena keadilan yang akan terwujud akan berdampak langsung pada rakyat, khususnya rakyat kelas menengah ke bawah. Dalam hal ini rakyat lah yang berhak bersuara bagaimana sistem zakat yang akan membawa mereka pada kesejahteraan. Sehingga kebijakan-kebijakan yang disusun tidak hanya menjadi

${ }^{28}$ Muhammad Kambali, "Paradigma Sistem Kapitalisme Dan Islam Tentang Welfare State," JES (Jurnal Ekonomi Syariah), 2019, https://doi.org/I0.30736/jesa.v4i1.55. 
kebijakan yang ,sekali baca langsung kabur ${ }^{\text {ee }}$ Tidak dirasakan manfaatnya oleh rakyat dan hanya menumpuk tanpa realisasi kebijakan itu sendiri.

Terbukti pada zaman Umar ibn Abdul Aziz, zakat telah direalisasikan secara nyata dan sukses sampai-sampai pernah tak ditemukan lagi orang fakir yang berhak menerima zakat. Yahya ibn Said, seorang petugas amil zakat pada masa Umar ibn Abdul Aziz (I22 H), menuturkan, Khalifah Umar ibn Abdul Aziz telah mengutusku untuk mengumpulkan zakat orang Afrika. Kemudian aku menariknya dan aku minta dikumpulkan orang-orang fakir yang membutuhkannya tapi ternyata tidak ada seorang pun dari kalangan itu yang mengambilny $\mathrm{a}^{29}$

\section{E. Simpulan}

Penetapan kebijakan tentang Pengelolaan Zakat diawali oleh UU No. 38 Tahun 1999, dari sinilah pemerintah menunjukkan keseriusan untuk mengoptimalkan kesejahteraan rakyat melalui isntrumen zakat. Undang- Undang tersebut selain menetapkan kewajiban pemerintah memberikan perlindungan, pembinaan dan pelayanan kepada muzakki (pemberi zakat), mustahiq (penerima zakat) dan amil zakat (pengelola zakat). Keseriusan pemerintah terhadap zakat semakin diperkuat oleh amandemen UU No. 38 Tahun 1999 menjadi UU No. 23 Tahun 20II tentang pengelolaan zakat yang salah satunya menetapkan zakat sebagai kredit pajak.

Kebijakan-kebijakan yang menurut sebagian kalangan bahkan tidak mengentaskan kemiskinan sama sekali padahal tujuan disusunnya kebijakan zakat itu sendiri demi untuk kesejahteraan rakyat. Akan tetapi kebijakan- kebijakan yang banyak dibuat malah membuat rakyat terbebani. Dengan kondisi rakyat yang terbebani, maka letak keadilan lagi-lagi dipertanyakan. Peran pemerintah jelas sebagai pembuat kebijakan yang berguna untuk kemashlahatan rakyat. Padahal nilai keadilan begitu dasar dan menjadi pondasi berdirinya bangunan zakat. Jika nilai keadilan saja sudah luntur dan masing-masing dari kita mengacuhkannya tak ada bedanya dengan mengahancurkan jism zakat. Padahal zakat

\footnotetext{
${ }^{29}$ Nabhani, Taqiyuddin, 2003. An Nizham Al Iqtishadiyah Fi Al Islam. Beirut: Darul Ummah.
}

Volume. 9/No. I/Januari 202I A1-Iqtishod | 53 
Eksistensi nilai al-Adalah ....

adalah anggota tubuh keimanan.

Restrukturisasi kebijakan zakat di Indonesia sebaiknya mengacu pada aspek-aspek falsafah yang membentuk bangunan zakat. Dengan mengembalikan ke falsafah maka segala pelaksanaan yang mewakili ruh zakat akan terwujud. Sistem yang berkeadilan, pemertaan pendapatan, distribusi dan redistribusi yang tidak kenal disparitas (ketimpangan) kemudian terwujudnya suatu kesejahteraan rakyat.

\section{F. Daftar Pustaka}

Al-Quran Al-Kariim

Ali, Mohammad Daud. 1998. Sistem Ekonomi Islam Zakat dan Wakaf. Jakarta: UI Press

Athoillah, M. Anthon dan Bambang Q-Anees. 2013. Filsafat Ekonomi Islam. Yogyakarta: Sahifa.

Chapra, M. Umar. 1985. Toward a Just Monetary System. Leiceste: UK Foundation.

Friedrich, Carl Joachim. 2004. Filsafat Hukum Perspektif Historis. Bandung: Nuansa dan Nusa Media.

Ibnu Qayyim, al-Jauziyyah, 1995. Zaad al-Ma'ad, Kuwait: Daar el-Fikr, Juz 2

Jusmaliani, dkk. 2005. Kebijakan Ekonomi dalam Islam. Yogyakarta: Kreasi Wacana.

Karim, Adiwarman. 2003. Ekonomi Makro Islami. Jakarta: IIIT Indonesia.

Kambali, Muhammad. "Analisis Peran Negara Di Bidang Ekonomi Dalam Prespektif Sistem Kapitalisme, Sosialisme, Dan Ekonomi Islam.” JES (Jurnal Ekonomi Syariah), 2016. https://doi.org/I0.30736/jes.vIiI.2.

__. "Paradigma Sistem Kapitalisme Dan Islam Tentang Welfare State." JES (Jurnal Ekonomi Syariah), 2019. https://doi.org/I0.30736/jesa.v4iI.55.

Kementerian Keuangan Republik Indonesia. 2012. Laporan Kajian Islamic Publik Finance.

Nabhani, Taqiyuddin. 2003. An Nizham Al Iqtishadiyah Fi Al Islam. Beirut: Darul Ummah.

54| A1-Iqtishod Volume. 9/No. I/Januari 202I 
Nasa ${ }^{e e}$ I, al. Sunan al Nasa ï. 8 Juz. Bairut: Dar al Kitab.

Qardhawi, Yusuf. 2007. Norma dan Etika Ekonomi Islam. Jakarta: Gema Insani Press

Schacht, Joseph. Encyclopedia of Islam, first ed., s.v. „zakat ${ }^{e e}$.

Sugiyono, 2014 Metode PenelitianBisnis, Alfabeta: Bandung,

Suwarsono. 1992. Pendapatan dan Belanja Negara dan Regulasi Ekonomi dalam Ekonomi Islam dalam Sistem Ekonomi Islam. Yogyakarta: Tiara Wacana dan LP3EI UII. 